\title{
PEMBENTUKAN RUANG BERHUNI KOLEKTIF DI KELURAHAN PEGADUNGAN DAMPAK PANDEMI COVID-19
}

\author{
Florencia Sentosa1), Budi Adelar Sukada ${ }^{2)}$ \\ 1)Program Studi S1 Arsitektur, Fakultas Teknik, Universitas Tarumanagara, florenciasentosa@gmail.com \\ 2)Program Studi S1 Arsitektur, Fakultas Teknik, Universitas Tarumanagara, budisukada@yahoo.com
}

\begin{abstract}
Abstrak
Pandemi Covid-19 yang menyerang penduduk Indonesia sejak Maret 2020 memberikan pengaruh terhadap cara berhuni manusia. Walaupun pandemi ini mungkin akan berakhir, namun dampak yang dihasilkan akan bertahan dalam waktu yang panjang, Aktivitas masyarakat sehari-hari menjadi terganggu dan terhambar khususnya masyarakat di pinggir perkotaan seperti di Kelurahan Pegaadungan yang mana untuk melakukan aktivitasnya harus berkomuter ke pusat kota. Hal ini menyebabkan interaksi sosial berkurang, interaksi dengan alam terbatas, dan peningkatan penggunaan teknologi yang akan berdampak pada penurunan kesehatan fisik dan mental manusia. Oleh karena itu, dibutuhkan wadah arsitektur baru dengan program rekreasi dan bekerja di skala lingkungan sebagai ruang berhuni kolektif yang dapat memberikan kemudahan bagi masyarakat lokal untuk beraktivitas. Untuk mencapai tujuan tersebut, diperlukan pengumpulan data dan analisis terkait lokasi, target pelaku, isu dan permasalahan yang terjadi. Penerapan Wellness Architecture dengan Pendekatan Desain Biofilik sebagai metode perancangan, seperti penggunaan udara alami, cahaya alami, dan koneksi alam ke dalam bangunan diharapkan dapat menciptakan arsitektur yang ideal dan sehat bagi kesejahteraan fisik, emosional, dan keseimbangan dalam berhuni. Sehingga dapat menciptakan permukiman dan lingkungan yang baik, tangguh, dan berkelanjutan.
\end{abstract}

\section{Kata kunci: Covid-19; Lingkungan; Rekreasi dan Bekerja}

\begin{abstract}
Covid-19 pandemic that attacks the population of Indonesia since March 2020 affects the human way of living. Even though this pandemic will probably end, the impacts will last for a long time. People's daily activities are disrupted and hampered, especially those in the suburban area such as in Pegadungan Sub-districts which to carry out the activities they have to commute o the center of the city. This causes less social interaction, limited interaction with nature, and increases technology using that impact human physical and mental health deterioration. Therefore, a new architectural space with recreation and work programs on a neighborhood scale is needed as a collective dwelling space that can provide benefits for local communities to do their activities. To achieve this goal, data and analysis are needed relating to the location, user target, issues, and problems that occur. The application of Wellness Architecture with a Biophilic Design Approach as a design method, such as the use of natural air, natural light, and natural connections into the buildings, is expected to create an ideal and healthy architecture for physical, emotional well-being, an balance in living. So that, it can create good, resilient, and sustainable settlements and environments.
\end{abstract}

Keywords: Covid-19; Neighborhood; Recreation and Work 


\section{PENDAHULUAN}

\section{Latar Belakang}

Pandemi Covid-19 yang menyerang dunia pada awal tahun 2020 memberikan pengaruh besar terhadap cara berhuni karena memicu adanya perubahan pada perilaku dan gaya hidup manusia, Protokol-protokol baru, seperti work from home (WFH), physical distancing, dan sebagainya mulai diberlakukan untuk mengurangi resiko penyebaran virus. Hal ini menyebabkan masyarakat tidak dapat melakukan aktivitasnya dengan normal dan terpaksa harus beradaptasi dengan kondisi tersebut. Walaupun di kemudian hari pandemi ini mungkin akan berakhir, namun dampaknya akan bertahan dalam jangka waktu yang panjang.

Pembatasan moda transportasi, pemberlakuan WFH dan physical distancing yang berlangsung lama akan memberikan dampak terhadap keberlangsungan hidup manusia. Cara bekerja WFH akan semakin berkembang, aktivitas manusia akan semakin bergantung pada tenologi digital, serta interaksi sosial dan interaksi alam akan semakin terbatas. Hal ini menyebabkan terjadinya ketidakseimbangan dalam berhuni. Khususnya di kawasan yang terletak di pinggir kota, yang mana untuk melakukan aktivitas sehari-harinya harus berkomuter ke pusat kota. Namun, dengan adanya pandemi Covid-19, sebagian besar aktivitasnya menjadi terganggu dan terhambat. Aktivitas yang sebagian besar dilakukan dalam rumah yang lama-kelamaan akan berakibat pada rasa terisolasi dan cabin fever yang berdampak pada penurunan kesehatan fisik dan mental manusia.

\section{Rumusan Permasalahan}

Berdasarkan latar belakang dan isu yang diangkat, maka dapat dirumuskan masalah sebagai landasan perancangan arsitektur, yaitu: 1) Bagaimana arsitektur dapat memberikan solusi terhadap perubahan gaya hidup, perilaku, dan cara berhuni manusia dampak Pandemi Covid19 ? 2) Bagaimana solusi untuk menghadirkan ruang baru yang bersifat responsif terhadap aktivitas masyarakat dan memberikan peluang maksimum untuk dapat berinteraksi dengan sesama dan alam yang terdampak Pandemi Covid-19?

\section{Tujuan}

Tujuan yang ingin dicapai dari penelitian dan perancangan ini, yaitu: 1) Menjadi ruang berhuni kolektif di skala neighborhood yang diharapkan dapat memberikan dampak positif bagi masyarakat dan lingkungan, 2) Masyarakat tetap mampu menjalankan aktivitasnya secara produktif dan dapat memberikan peluang maksimum untuk berinteraksi dengan sesama dan berinteraksi dengan alam yang berpengaruh terhadap peningkatan kesehatan fisik dan mental, 3) Masyarakat di pinggir kota dimudahkan dengan adanya fasilitas di lingkungan neighborhood yang responsif terhadap aktivitasnya tanpa perlu berkomuter ke pusat kota, dan 4) Berkontribusi dalam pembentukan permukiman dan kota yang baik, tangguh, dan berkelanjutan.

\section{KAJIAN LITERATUR}

\section{Pengertian Berhuni (Dwelling)}

Menurut Partridge (1961: 901), berhuni (dwelling) berasal dari kata Dwellan (dalam Bahasa Inggris Kuno), yang artinya mengembara (to wander), bertahan hidup (to linger), dan menetap (to tarry). Maka, untuk bertahan hidup manusia tidak hanya menetap di suatu tempat saja, namun harus berkelana/mengembara. Norberg-Schulz (1985:13), menjelaskan bahwa dalam berhuni terdapat4 tahap, yaitu: 1) Settlement sebagai Natural Dwelling, 2) Urban Space sebagai Collective Dwelling, tempat dimana manusia saling bertemu dalam keberagamannya, 3) Institution sebagai Public Dwelling, tempat dimana manusia memiliki persetujuan dan kesamaan nilai dan minat sehingga membentuk suatu komunitas, 4) Home/house sebagai Private Dwelling, tempat dimana kehidupan individu berlangsung yang menghasilkan identitas pribadi. 
Tujuan berhuni bagi manusia sebagai subjek yang mengatur kehidupan adalah bertahan hidup dan mempertahankan eksistensinya. Dalam mempertahankan eksistensi, manusia harus memenuhi kebutuhan kehidupan sehari-hari dengan melakukan suatu usaha/aktivitas. Menurut Alli (2008) dalam Adesoye dan Ajibua (2015:78), aktivitas manusia dalam sehari terbagi menjadi 3 segemen, yaitu: 1) Existence time, yaitu waktu yang digunakan untuk melakukan hal-hal untuk kepenuhan biologis (physiological needs: makan, tidur, minum), 2) Subsistence time, yaitu waktu yang digunakan untuk mencari nafkah atau untuk mempersiapkan kehidupan (seperti bekerja, belajar), dan 3) Discretionary/Leisure time, yaitu waktu luang yang digunakan untuk melakukan aktivitas pilihan (seperti istirahat, sosialisasi, hiburan).

Berhuni merupakan tata cara manusia berada di bumi dan mampu beradaptasi terhadap suatu kondisi. Berhuni tidak terbatas pada ruang fisik spesifik yang terkait dengan rumah, juga tidak harus stasioner. Kondisi mental makhluk inilah yang menentukan apa artinya berhuni, berkaitan dengan perasaan damai dan emosi positif.

\section{Well-being and Wellness Architecture}

Well-being atau wellness adalah kondisi individu atau kelompok dimana beradai di kondisi yang positif secara fisik, mental, dan sosial. Kesejahteraan emosional mengacu pada kualitas emosional individu yang dipengatuhi oleh berbagai faktor, seperti demografis, ekonomi, dan situasi. Misalnya, timbulnya Pandemi Covid-19 yang menurunkan kesehjahteraan emosional hingga $74 \%$. Hubungan antara pikiran dan tubuh yang begitu kuat menyebabkan keadaan mental dan fisik saling berhubungan baik secara positif maupun negatif. Peningkatan kesejahteraan dapat meningkatkan kemampuan mengatasi maslaah, harga diri, kinerja, produktivitas di tempat kerja, dan bahkan umur panjang. Sedangkan penurunan kesejahteraan emosional dapat mengakibatkan masalah kesehatan mental, seperi stres, depresi, dan krisis.

Wellness Architecture adalah praktik arsitektur yang mengandalkan seni dan ilmu merancang lingkungan binaan yang bertujuan untuk mendorong keseimbangan yang harmonis antara kesejahteraan fisik, emosional, kognitif, dan spiritual (Daniels, 2019). Kesehatan, kesejahteraan, dan kenyamanan manusia adalah pertimbangan desain intama yang menambah pondasi pada praktek desain yang berkelanjutan dan regeneratif.

\section{Leisure Activity}

Leisure berasal dari Bahasa Latin, yaitu licere yang berarti diizinkan (to be permited) atau menjadi bebas (to be free) (Hasana, 2017:5). Manfaatnya berupa dapat meningkatkan kesejahteraan jasmani, meningkatkan kesehatan mental dan emosional, membuat kita dapat mengenali kemampuan diri, meningkatkan daya kerja dan prduktivitas, serta mengingkatkan kehidupan bermasyarakat. Setiyani (2012:17) menjelaskan bahwa kegiatan leisure terdiri dari 3 kegiatan, yaitu: 1) Kegiatan relaksasi, terdiri dari kegiatan relaksasi aktif yang sifatnya produktif (berolahraga, bermain musik, menari, bermain, dan sebagainya) dan kegiatan relaksasi pasif (menonton film, mendengarkan musik, membaca, dan sebagainya); 2) Kegiatan hiburan, yaitu kegiatan rekreasi yang dapat mempromosikan penguasaan keterampilan, seperti olahraga, hobi, dan kesenian atau rekreasi seperti menonton bioskop, bermain game, makan di kafe, bertemu teman, dan sebagainya; dan 3) Kegiatan pengembangan diri, yaitu kegiatan yang meningkatkan kesadaran dan mengembangkan bakat serta potensi.

Rekreasi adalah kegiatan yang menyehatkan paa aspek sosial, fisik, dan mental. Rekreasi merupaan aktivitas sebagai pelenkap kerja yang dapat menyeimbangi antara kehidupan da dunia pekerjaa, Oleh karena itu, rekreasi merupakan kebutuhan semua orang, Kegiatan yang umum dilakukan untuk rekreasi adalah berolahrga, bermain, bertemu rekan, hobi, pariwisaa, dan lain-lain. Manfaatnya adalah sarana sosialisasi, melepas ketegangan dan stress, memperat hubungan, meningkatkan kepuasan hidup. Tujuannya adalah membina hubungan manusia, 
melestarikan alam, mendapat pengalaman baru, memupuk kreativitas, meningkatkan rasa percaya diri, pelepas lelah, kebosanan, dan kepenatan, sebagai pemenuhan fungsi sosial dan kesegaran jasmani.

\section{METODE}

Metode yang digunakan dalam penelitian berupa pengumpulan data dan analisis-sintesis data berdasarkan tema, permasalahan dan isu yang diangkat dalam perancangan. Sumber data dan informasi didapat melalui 1) Studi literatur: Literatur yang digunakan adalah The Concept of Dwelling oleh Christian Norberg-Schulz (1985) dan Building, Dwelling, Thinking oleh Martin Heidegger (1954) terkait teori berhuni sebagai tema besar perancangan; 2) Observasi atau pengamatan: Pengamatan langsung dilakukan di lokasi perancangan yang terletak di Kelurahan Pegadungan; dan 3) Dokumentasi.

Sedangkan metode yang digunakan dalam perancangan berupa Pendekatan Desain Biofilik yang dikemukakan ileh Steven Kellert. Desain Biofilik adalah pendekatan desain yang bertujuan untuk memenuhi kebutuhan manusia akan alam di lingkungan binaan. Selain itu, alam juga sangat berpengaruh bagi kondisi fisik dan psikologi manusia. Pada masa pandemi ini yang mengakibatkan berkurangnya interaksi manusia dengan alam karena adanya peningkatan penggunaan teknologi, WFH, phsical distancing, dan sebagaiya. Penerapan Desain Biofilik menghadirkan ruang hijau, sirkulasi udara dan cahaya alami dengan menghubungakan manusia dengan alam untuk meningkatkan kualitas hidup yang mempengaruhi kesehatan dan kesjahteraan fisiologi maupun psikologi manusia, menciptakan arsitektur yang lebih sehat, meningkatkan nilai positif, dan mengurangi tingkat stres. Penerapan Desain Biofilik dibagi menjadi 3 kategori, yaitu Nature in the Space, Nature Analogues, dan Nature of the Space (Browning et al., 2014:5).

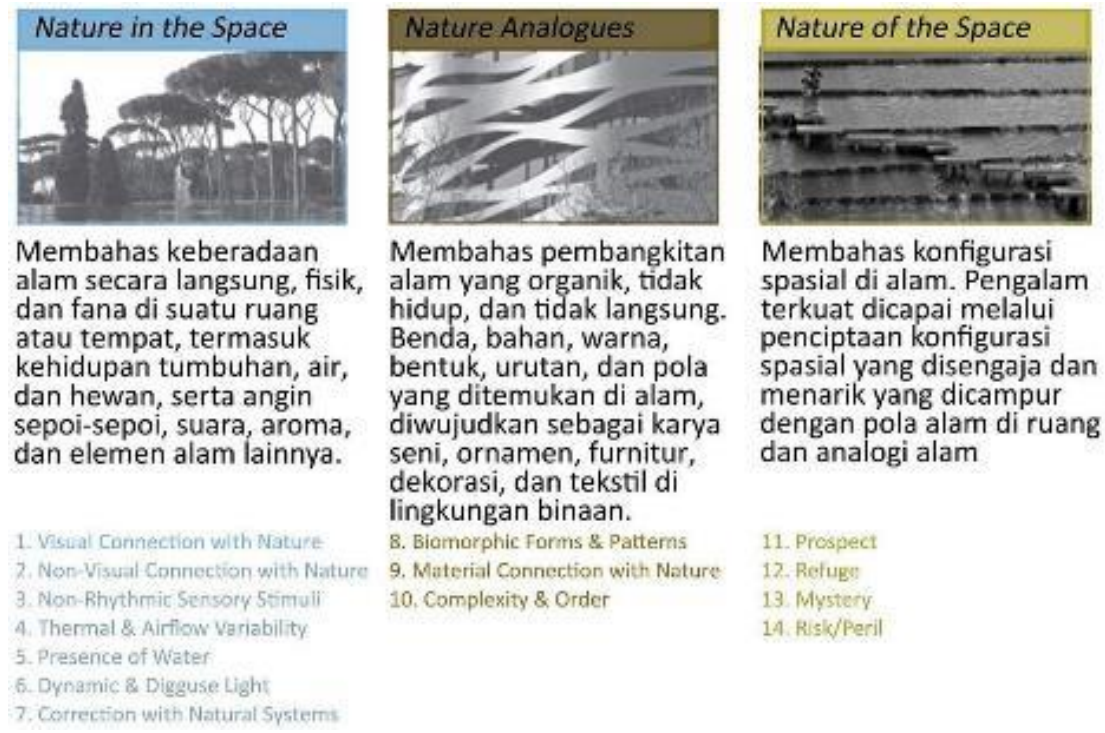

Gambar 1. Kategori Penerapan Desain Biofilik Sumber: Terrapin Bright Green, 2014

\section{DISKUSI DAN HASIL}

\section{Skala 'Neighborhood' Lingkungan}

Dampak Pandemi Covid-19 yang mengakibatkan adanya perubahan cara berhuni manusia, seperti WFH menyebabkan masyarakat di seluruh dunia terpaksa tinggal lebih dekat dengan rumah dan adanya perubahan gaya hidup yang lebih lokal. Pandemi telah memperkuat alasan untuk membuat lingkungan yang leih mandiri, seperti contohnya yang diterapkan oleh Kota Melbourne untuk menempatkan program belanja, rekreasi, bekerja, dan sebagainya dalam 
waktu 20 menit dari rumah penduduknya ( 20 minute neighborhood). Riset menunjukkan bahwa 20 menit adalah waktu maksmial orang mau berjalan kaki untuk memenuhi kebutuhan seharihari mereka secara lokal, seperti mengakses fasilitas dan layanan kesehatan setempat, sekolah, bekerja, berbelanja, dan sebagainya. Perjalanan 20 menit ini mempresentasikan 800 meter berjalan kaki dari rumah ke tujuan dan perjalanan kembali atau 10 menit berjalan kaki ke tujuan dan 10 menit kembali ke rumah (Gunn et al., 2016).

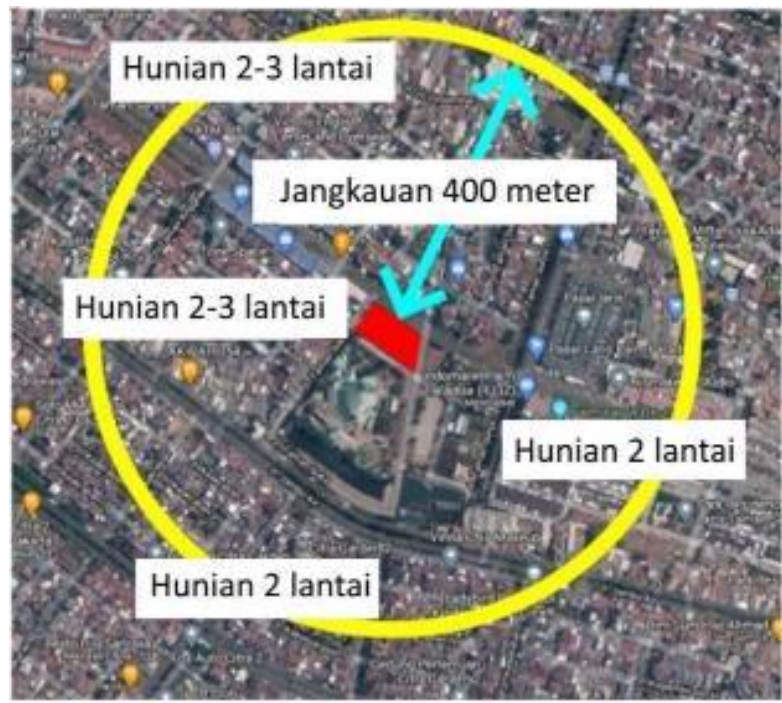

Gambar 2. Jangkauan Skala 'Neighborhood' Lingkungan

Sumber: Penulis, 2020

\section{Identifikasi dan Analisis Tapak}

Lokasi tapak berada di Jalan Taman Surya 5, Kelurahan Pegadungan, Kecamatan Benda, Jakarta Barat. Lokasi ini terletak di paling pinggir dan barat Kota Jakarta, serta didominasi oleh permukiman penduduk, khususnya permukiman menengah. Kelurahan Pegadungan berbatasan langsung dengan Kecamatan Benda, Tangerang pada sisi barat.
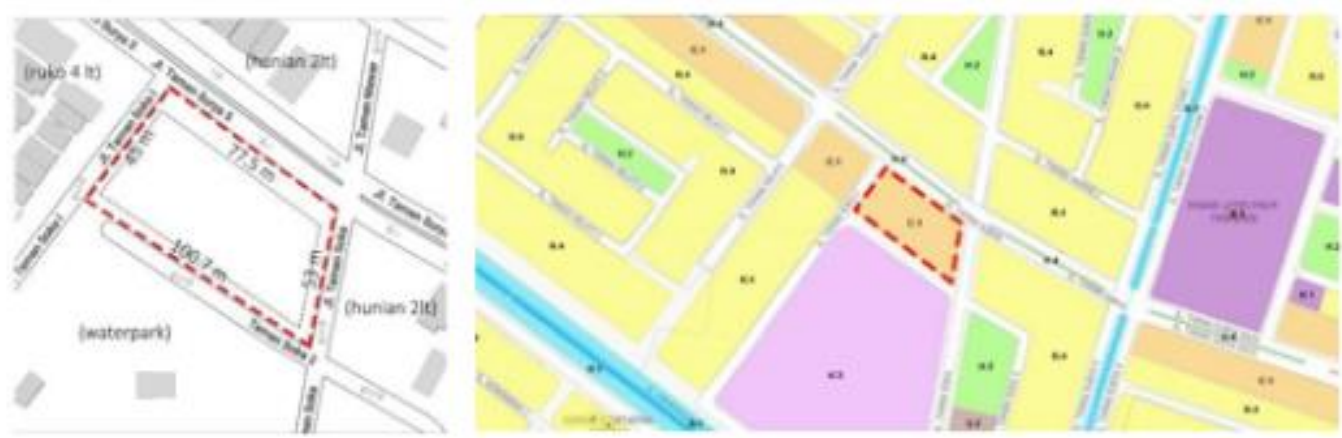

Gambar 3. Lokasi Tapak di Pegadungan (kiri) dan Zonasi Tapak (kanan) Sumber: Penulis, 2020

Tapak dikelilingi oleh 4 jalan dengan Jl. Taman Surya 5 sebagai jalan utama selebar 13 meter. Sisi depan tapak berbatasan dengan JI. Taman Surya 5 dan hunian menengah 2-3 lantai. Sisi kanan tapak berbatasan dengan JI. Taman Soka 1 selebar 6.7 meter dan ruko dengan ketinggian 4 lantai. Sisi kiri tapak berbatasan dengan Jl. Taman Soka selebar 9 meter, serta tanah kosong dan hunian 2 lantai. Sisi belakang tapak berbatasan dengan Jl. Taman Soka 2 selebar 8 meter dan waterpark. 


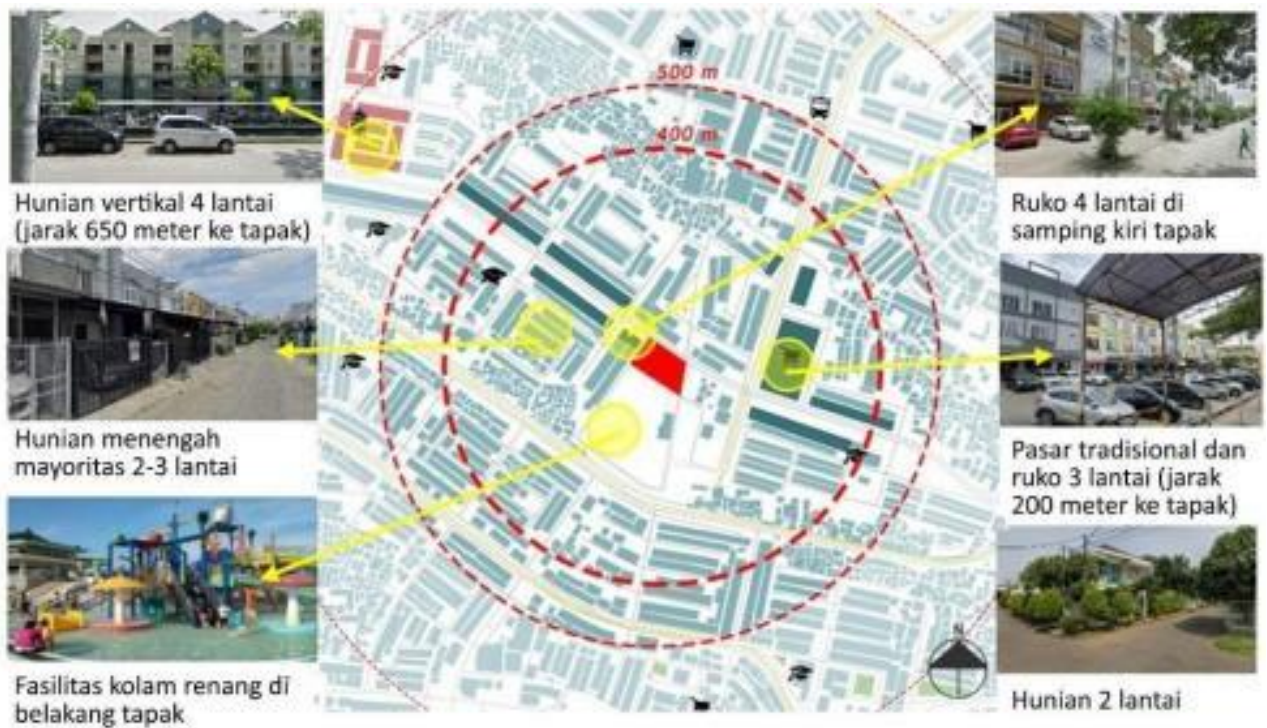

Gambar 4. Mapping Tapak Mezzo

Sumber: Penulis, 2020

Dalam radius 500 meter didominasi oleh hunian menengah 2-3 lantai. kawasan ini masih minim fasilitas bekerja dan ruang publik terbuka untuk menunjang aktivitas sehari-hari, sehingga masyarakt harus berkomuter ke pusat kota untuk memenuhi kebutuhannya. Fasilitas yang terdapat di sekitar tapak antara lain: pasar tradisional, pendidikan, ruko, dan fasilitas water park berbayar. JI. Taman Surya 5 sebaai jalan utama tapak merupakan hierarki jalan lokal. Kedua hierarki jalan dapat dilalui oleh kendaraan bermotor. Namun, jalan lokal merupakan jalan gang perumahan yang bersifat lebih privat. Ketinggian bangunan di sekitar tapak didominasi oleh bangunan rendah, dengan bangunan komersial 3-4 lantai dan bangunan hunian 1-2 lantai.

\section{Usulan Aktivitas dan Program}

Pada tahun 2020-2030, Indonesia diproyeksikan akan mengalami bonus demografi dimana jumlah penduduk usia produktif (15-64 tahun) lebih banyak dibandingkan dengan jumlah penduduk usia di atas atau di bawah usia proroduktif (Kemenkeu, 2017:5). Saat ini, dunia didominasi oleh kaum muda, dengan 30,78\% Generasi $Y$ dan 34,05\% Generasi $Z$ yang akan menjadi penentu masa depan dunia. Dari tabel lintas generasi dan karakteristiknya dapat diperoleh usulan aktivitas dan program dalam perancangan.

Tabel 1. Lintas Generai dan Karakteristik

\begin{tabular}{|c|c|c|c|c|c|c|}
\hline & \multicolumn{2}{|c|}{ Gen $X(1965-1980)$} & \multicolumn{2}{|c|}{ Gen Y Milennials (1981-1994) } & \multicolumn{2}{|c|}{$\operatorname{Gen} Z(1995-2010)$} \\
\hline Era & \multicolumn{2}{|c|}{$\begin{array}{l}\text { Digital immigrant } \\
\text { (Era awal digital) }\end{array}$} & \multicolumn{2}{|c|}{$\begin{array}{l}\text { Digital Native } \\
\text { (Era Internet booming) }\end{array}$} & \multicolumn{2}{|c|}{$\begin{array}{l}\text { iGeneration } \\
\text { (Lahir pada masa digital berkembang) }\end{array}$} \\
\hline Characteristic & $\begin{array}{l}\text { Flexible } \\
\text { Informal } \\
\text { Skeptical }\end{array}$ & $\begin{array}{l}\text { Independent } \\
\text { Diversity } \\
\text { Risk-taker }\end{array}$ & $\begin{array}{l}\text { Competitive } \\
\text { Open-minded } \\
\text { Multitasking }\end{array}$ & $\begin{array}{l}\text { Confidence } \\
\text { Seeking Challenge } \\
\text { Visioner \& }\end{array}$ & $\begin{array}{l}\text { Global } \\
\text { Entrepreneurial } \\
\text { Progressive }\end{array}$ & $\begin{array}{l}\text { Creative } \\
\text { Indivuality } \\
\text { Collaborative }\end{array}$ \\
\hline Communication & \multicolumn{2}{|c|}{$\begin{array}{l}\text { Email } \\
\text { Text message }\end{array}$} & \multicolumn{2}{|l|}{$\begin{array}{l}\text { Text } \\
\text { Social media }\end{array}$} & \multicolumn{2}{|c|}{$\begin{array}{l}\text { Hand-held } \\
\text { Facetime/video call }\end{array}$} \\
\hline Teamwork & \multicolumn{2}{|c|}{ Prefer individual work } & \multicolumn{2}{|c|}{ Harnessing collective power } & \multicolumn{2}{|c|}{ Prefer collaborative work environment } \\
\hline $\begin{array}{l}\text { Working } \\
\text { type }\end{array}$ & \multicolumn{2}{|c|}{$\begin{array}{l}\text { Starter Entrepreneurial (55\%) } \\
\text { Office employees }\end{array}$} & \multicolumn{2}{|c|}{$\begin{array}{l}\text { Start-up business, Entrepreneurial } \\
\text { Remote working (dampak covio) } \\
\text { Online business } \\
\text { Creative business } \\
\text { Freelancer } \\
\text { Based on hobbies }\end{array}$} & \multicolumn{2}{|c|}{$\begin{array}{l}\text { Start-up, Entrepreneurial } \\
\text { Remote working (dampak COVID) } \\
\text { Online business } \\
\text { Creative business } \\
\text { Freelancer } \\
\text { Based on internet \& social media } \\
\text { Collaborative workers }\end{array}$} \\
\hline $\begin{array}{l}\text { Work-life } \\
\text { balance }\end{array}$ & \multicolumn{2}{|c|}{$\begin{array}{l}\text { Seek balance work-family } \\
\text { Work to live }\end{array}$} & \multicolumn{2}{|c|}{$\begin{array}{l}\text { Freedom \& flexibility } \\
\text { Blended lifestyle }\end{array}$} & \multicolumn{2}{|c|}{$\begin{array}{l}\text { Work-life balance } \\
\text { Wellnes \& wellbeing }\end{array}$} \\
\hline
\end{tabular}

Sumber: Penulis, 2020 


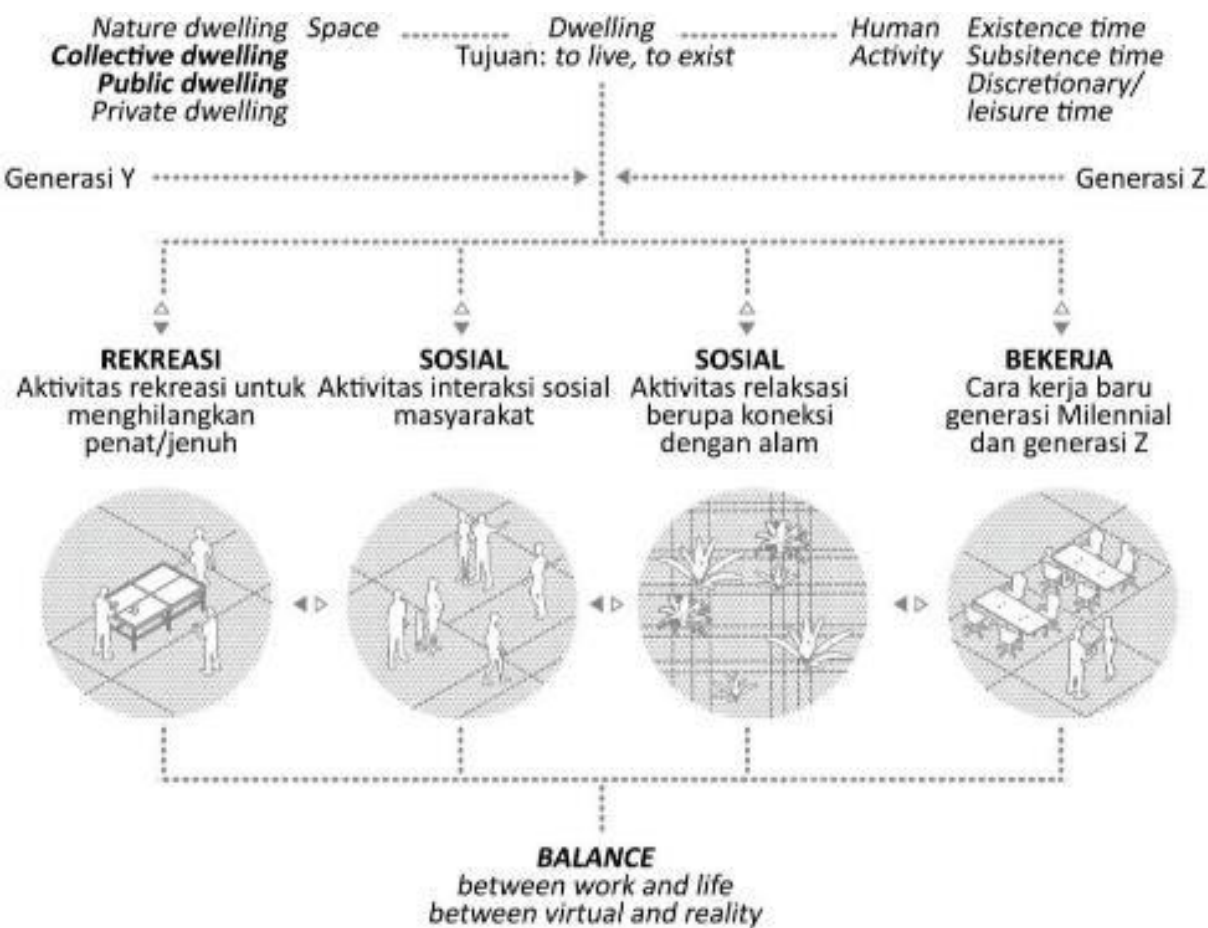

Gambar 5. Usulan Ide Program

Sumber: Penulis, 2020

Usulan perancangan berupa ruang publik yang memberikan peuang maksimum untuk memenuhi kebutuhan bekerja baru dan kegiatan waktu luang di masa depan dampak Pandmei Covid-19. Usulan program didasari akan kebutuhan Generasi Y dan Z, work-life balance, serta keseimbangan antara teknologi digital dan alam, sehingga memperoleh kehidupan yang lebih seimbang dan sehat secara fisik dan mental. Usulan program utama dibagi menjadi 2, yaitu Leisure: rekreasi, interaksi sosial, interaksi alam, dan Cara Bekerja Baru. Leisure merupakan program yang mewadahi aktivitas rekreasi aktif dan pasif untuk menghilangkan penat/jenuh sehagai peneimbang antara kegiatan bekerja dan kegiatan waktu luang, menghadirkan interaksi sosial dan interaksi dengan alam. Adanya interaski dengan alam dapat meningkatkan kesehatan disik dan metal penggunanya. Cara Bekerja Baru merupakan program yang mewadahi cara bekerja yang dipengaruhi oleh kebutuhan dan minat Generasi $Y$ dan Generasi Z, dengan cara remote working, kolarboratif, start-up, dan kreatif.

Tabel 2. Persentase Usulan Program

\begin{tabular}{|c|c|c|c|c|}
\hline DWELLING & \multicolumn{3}{|l|}{ PROGRAM BANGUNAN } & KARAKTER \\
\hline $\begin{array}{l}\text { COLLECTIVE } \\
\text { DWELLING } \\
\text { tempat dimana } \\
\text { manusia saling } \\
\text { bertemu dalam } \\
\text { keberagaman; untuk } \\
\text { bertukar produk, ide, } \\
\text { dan perasan }\end{array}$ & $\begin{array}{l}\text { LEISURE } \\
\text { Passmore (2003), leisure dibagi } \\
\text { menjadi } 3 \text { kategori: } \\
\text { - aktif (berorientasi pada tujuan) } \\
\text { - sosial (interaksi sosial) } \\
\text { - timeourt (pasif) }\end{array}$ & 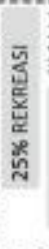 & $\begin{array}{l}\text { rea Fun Games } \\
\text { rea Digital + Sport Simulator } \\
\text { pen-air Cinems } \\
\text { 4. Kafe } \\
\text { 5. Food Bar } \\
\text { ¿ 6. Retail Microshops } \\
\text { 5 7. Plaza Multifungsi + Amphiteater } \\
\text { \& 8. Gardening Playground }\end{array}$ & $\begin{array}{l}\text { Terbuka } \\
\text { Menyenangkan } \\
\text { Koneksi dengan alam } \\
\text { Interaksi } \\
\text { Menyegarkan }\end{array}$ \\
\hline $\begin{array}{l}\text { PUBLIC } \\
\text { DWELLING } \\
\text { tempat dimana } \\
\text { manusia memiliki } \\
\text { persetujuan dengan } \\
\text { kesamaan nilai dan } \\
\text { minat }\end{array}$ & $\begin{array}{l}\text { CARA KERJA BARU } \\
\text { Cara kerja baru yang didorong oleh } \\
\text { minat generasi milennial dan Z: } \\
\text { start-up entrepreneurial, online, } \\
\text { creative, freelance, collaborative, } \\
\text { remote working }\end{array}$ & \multicolumn{2}{|c|}{ 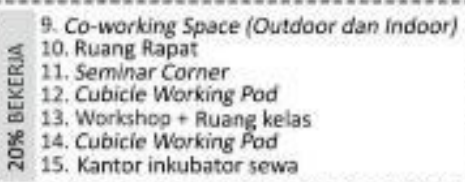 } & $\begin{array}{l}\text { Produktif } \\
\text { Terbuka } \\
\text { Koneksi dengan } \\
\text { alam } \\
\text { Kolaboratif } \\
\text { Terhubung }\end{array}$ \\
\hline \multicolumn{2}{|c|}{$20 \%$ PENUNJANG } & \multicolumn{2}{|c|}{$\begin{array}{l}\text { 16. Lobi }+ \text { Area Sterilisasi } \\
\text { 17. Manajemen Bangunan } \\
\text { 18. Servis }\end{array}$} & \\
\hline
\end{tabular}

Sumber: Penulis, 2020 


\section{Konsep Perancangan}

Ide Program berupa Collective Public Dwelling, ruang publik dimana manusia dapat saling bertemu yang memiliki kesamaan nilai dan minat, serta dapat bertukar ide, produk, wawasan, dan sebagainya dalam suatu lingkungan. Usulan program terdiri dari Leisure berupa rekreasi dan relaksasi dan Cara Kerja Baru (berdasarkan minat Generasi Y dan Z) sehingga dapat menciptakan keseimbangan antara pekerjaan dan kehidupan sehari-hari, serta dapat meningkatkan kesehatan fisik dan mental manusia dampak Pandemi Covid-10. Wellness Architecture juga diterapkan dengan menggunakan metode pendekatan Desain Biofilik - Nature in the Space, dengan menghadirkan ruang hijau, sirkulasi udara dan cahaya alami ke dalam bangunan, serta menghubungkan kembali koneksi manusia dengan alam. Konsep bangunan dianalisis dar fakta-fakta mengenai Pandemi Covid-19 dan dampak yang dihasilkan. Menurut berbagai sumber, penyebaran virus lebih beresiko 20 kali lipat di ruangan tertutup dengan sistem ventilasi yang buruk. Virus Covid-19 juga dapat bertahan pada suhu rendah dengan kelembaban ideal relatif 40-60\% (apabila kelembaban terlalu tinggi dapat meningkatkan kelangsungan hidup virus).
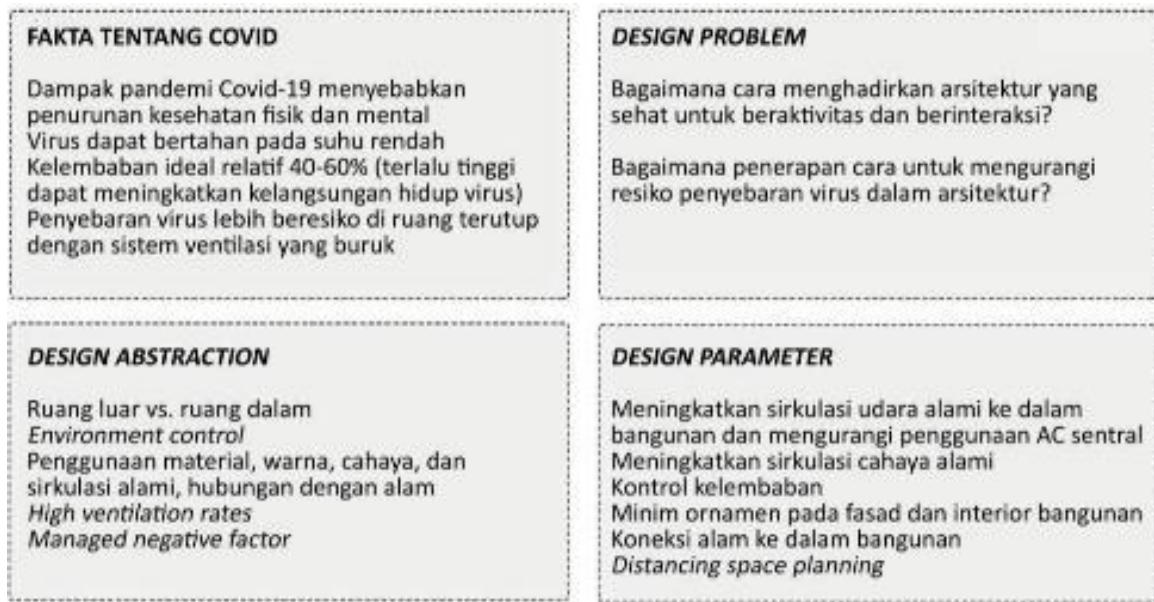

Gambar 6. Paramater Desain

Sumber: Penulis, 2020

Dari fakta diatas, diperoleh permasalahan dalam desain, yaitu cara menghadirkan arsitektur yang sehat untuk beraktivitas dan berinteraski, serta cara untuk mengurangi resiko penyebaran virus dalam arsitektur. Sehingga, yang perlu diperhatikan adalah meningkatkan sirkulasi udara alami ke dalam bangunan dan mengurangi penggunaan $A C$ sentral yang beresiko meningkatkan penyebaran virus, meningkatkan sirkulasi cahaya alami, mengontrol kelembaban dengan menggunakan ceiling fan dan penggunaan tanaman, minim ornamen pada fasad dan interior bangunan, koneksi alam ke dalam bangunan, serta penggunaan distancing space planning (diadaptasi dari protokol kesehatan yang dikeluarkan oleh WHO dan CDC).

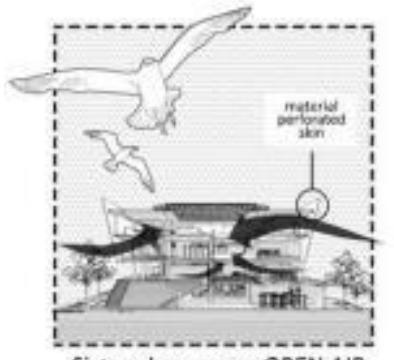

Sistem bangunan OPEN AIR memaksimalkan ventilasi alami

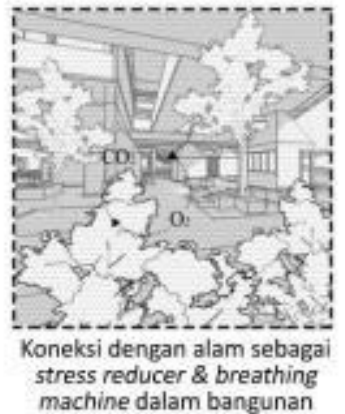

Gambar 7. Konsep Perancangan

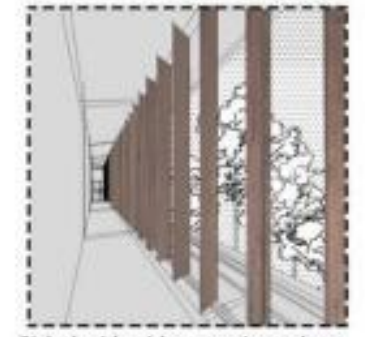

Sirkulasi koridor semi-outdoor, udara bebas masuk, namun tetap terlindung dari hujan

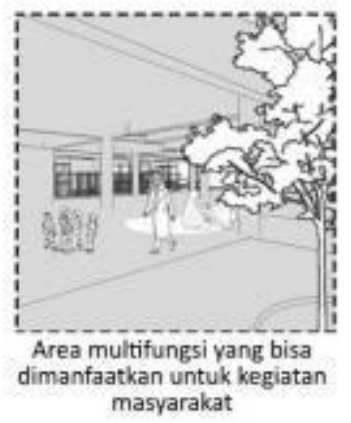

Sumber: Penulis, 2020 


\section{Hasil Analisis}

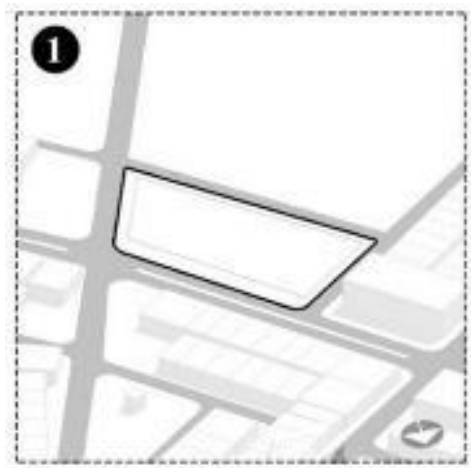

Tapak memiliki bentuk unit dengan luas $4500 \mathrm{~m}^{2}$. Tapak dikelilingi oleh 4 sisi jalan dan jalan utama berada di Timur Laut.

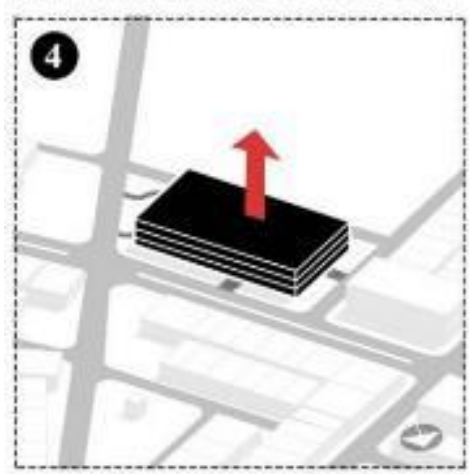

Massa ditinggikan menjadi 3 lantai menyesuaikan besaran program bangunan.

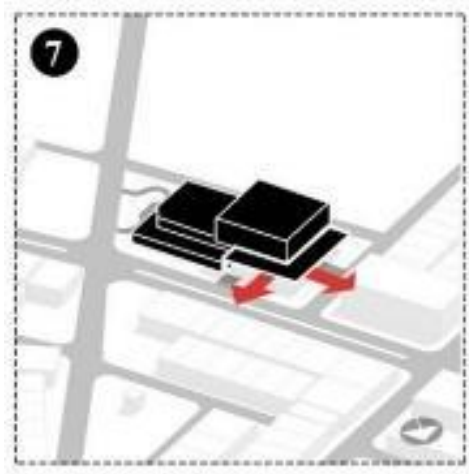

Sebagian lantai dasar bangunan dipotong sehingga membentuk area publik terbuka dengan pilotis yang terdiri dari program yang mengundang dan ramah pedestrian.

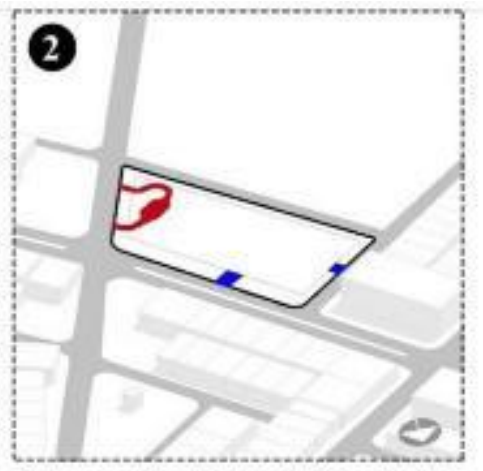

Menentukan akses kendaraan dan akses pedestrian. Akses kendaraan berada di Tenggara dan akses pedestrian berada di Timur Laut.

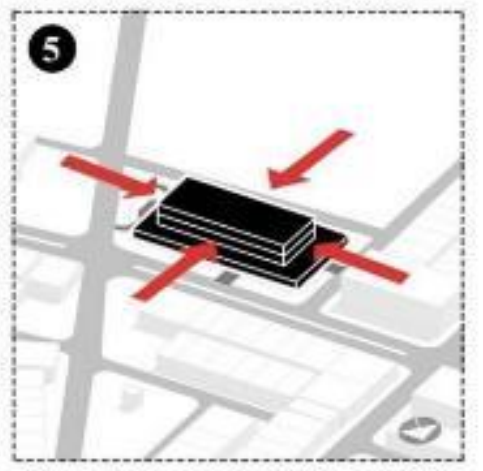

Pemotongan massa pada lantai 2 dan 3 untuk pemenuhan program outdoor

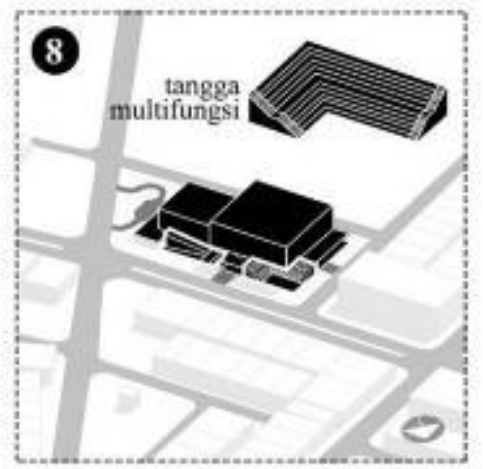

Penambahan sirkulasi ramp dan tangga yang dapat lansung mengakses lantai 2. Penambahan komponen tangga multifungsi, selain untuk mengakses lantai 2 , juga dapat difungsikan sebagai amphiteater dan gathering point.

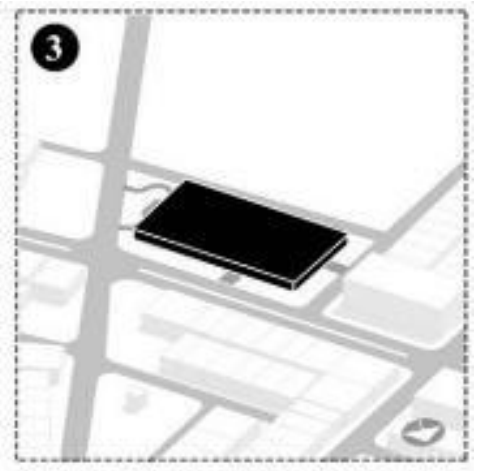

Membentuk massa berbentuk balok mengikuti urban fabric kawasan dengan memanfaatkan KDB semaksimalnya.

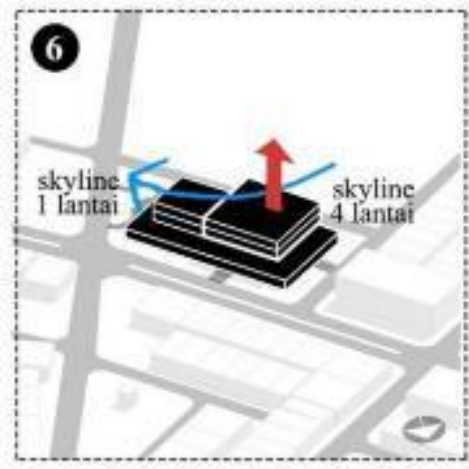

Penambahan 1 lantai pada sisi kanan untuk menyesuaikan besaran program dan $5 k y l i n e$ sekitar tapak. Penambahan massa ini menghasilkan pembayangan yang lebih besar ke massa sisi kiri.

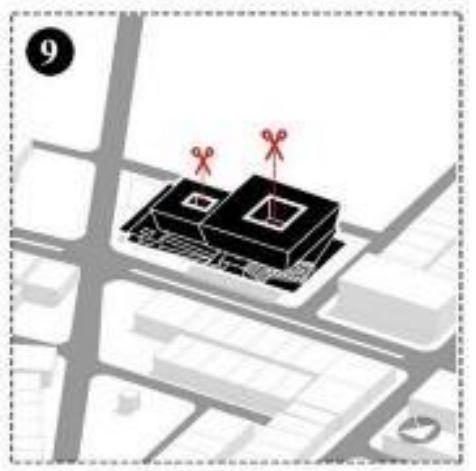

Penambahan void di tengah untuk memecah massa bangunan dan memghadirkan sirkulasi udara dan pencahayaan alami di seluruh lantai bangunan.

Gambar 8. Proses Gubahan Massa

Sumber: Penulis, 2020

Penggunaan pilotis pada bangunan, sehingga lantai dasar dapat difungsikan sebagai area publik bersifat outdoor yang mengundang dan ramah terhadap pedestrian, seperti 1) Tangga multifungsi: selain berfungsi sebagai sirkulasi vertikal dari lantai dasar menuju kafe (lantai 2), tangga ini dimanfaatkan sebagai amphitheater untuk pertunjukan temporer. Amphitheater juga dapat dimanfaatkan sebagai area duduk pengunjung yang ingin menikmati makanan/minuman dari kafe; 2) Gardening Playground: merupakan taman bermain anak yang dilengkapi dengan 
area tanam sebagai saranan edukasi dan area duduk orang tua untuk mengawasi anak-anaknya ketika sedang bermain; 3) Retail Microshops: merupakan retail-retail kecil dengan ukuran $2.4 \mathrm{x}$ $2.4 \mathrm{~m}^{2}$ yang tersebar dan dilengkapi dengan area duduk serta terkoneksi dengan elemen alam. Adanya elemen air pada tepi plaza sebagai elemen alam yan dapat berfungsi sebagai stress reducer. Pepohonan sebagai lanskap dan breathing machine dalam bangunan, 4) Plaza multifungsi: dapat dimanfaatkan untuk kegiatan masyarakat, seperti senam pagi bersama, acara tahunan, dan sebagainya.
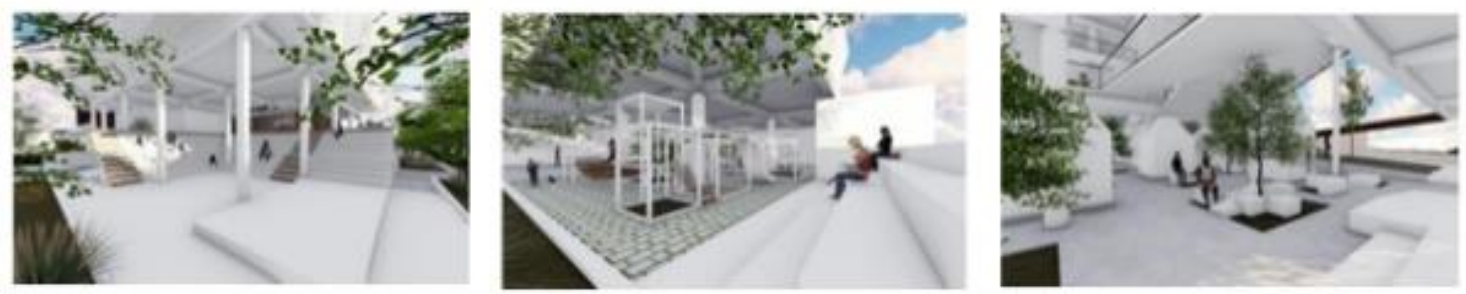

Gambar 9. Amphitheater (kiri), Gardening Playground (tengah), dan Retail Microshops (kanan) Sumber: Penulis, 2020

\section{KESIMPULAN DAN SARAN}

\section{Kesimpulan}

Program dalam perancangan ditentukan berdasarkan hasil analisis terhadap isu dan permasalahan yang terjadi di Indonesia, yaitu Pandemi Coivd-19 yang menghambat aktivitas sehaari- hari masyarakat di Kota Jakarta. Program Rekreasi dan Cara Kerja Baru diharapkan dapat memberikan manfaat bagi masyarakat lokal dan dapat menjadi ruang berhuni kolektif yang ideal dan sehat untuk generasi masa depan. Perancangan ini pun memiliki konsep bangunan open-air yang memaksimalkan penggunaan ventilasi alami dan terkoneksi dengan elemen alam. Dengan begitu, resiko penyebaran virus dapat dikurangi, interaksi sosial dan alam tetap terjaga, dan dapat mengurangi resiko penurunan kesehatan fisik dan mental pada manusia.

\section{Saran}

Pandemi Covid-19 secara langsung maupun tidak langsung menyebabkan berkurangnya interaksi sosial dan interaksi dengan alam yang berdampak terhadap penurunan kesehatan fisik dan mental, khusunya di kawasan pinggir perkotaan. Sehingga dibutuhkan ruang berhuni kolektif skala neighborhood yang memberikan peluang maksimal untuk berinteraksi dan bekerja secara produktif sehingga membentuk permukiman yang baik dan sehat.

\section{REFERENS}

Adesoye, A.A. dan M.A. Ajibua. (2015). Exploring the Concept of Leisure ant Its Impact an Quality of Life. American Journal of Social Science Research, Vol. 1 No.2.

Browning, W.D., Ryan, C. Clancy, J. (2014). 14 Patterns of Biophilic Design. New York: Terrapin Bright Green, LCC.

Daniels, S. (2019). 3 Example of Wellness Architecture of Your Home. Dig this Design. Retrieved December 30, 2020, from https://digthisdesign.net/design-architecture/3-examples-ofwellness-architecture-for-your-home/

Gunn, L., King, T., Mavoa, S. (2016). Identifying Destination Distances that Support Walking Trips in Local Neighbohoods. Research Gates. Retrieved December 30, 2020, from https://www.researchgate.net/publication/308039582 Identifying destination distances that support walking trips in local neighborhoods

Hasana, D.W. (2017). Pemanfaatan Waktu Belajar Siswa Diluar Jam Belajar Sekolah pada Siswa SMA Negeri 1 Bangkinang. JOM FISIP, Vol. 4 No.2.

Kemenkeu RI. (2017). Transparansi Informasi Kebijakan Fiskal. Media Keuangan, Vo 12, No. 119. 
Norberg-Schulz, C. (1985). The Concept of Dwelling: On the Way to Figurative Architecture. New York: International Publications, Inc.

Partridge, E. (1985). A Short Etymological Dictionary of Modern English. London: Routledge Setiyani, A., 2012, Mengisi Waktu Luang Pada Siswa Negeri 1 Ngemplak, Skripsi, Fakultas Ilmu Pendidikan, Universitas Negeri Yogyakarta, diunduh 30 Desember 2020, http://eprints.uny.ac.id/9557/2/bab\%202\%20-NIM\%2005104241015.pdf 
